height, 4 inches in diameter, the sides are made of wire mosquito netting drawn into the form of a cylinder and laced with copper wire. The top is similar to the one already described which is used on the glass jars; while the bottom is made in the same way but without the groove. The lower edge of the wire is tacked securely to the wooden surface. In making these cages netting, 20 inches wide, was used, the finished edge always being placed at the top. These cages were sunk about 8 inches into the ground and furnish conditions which are as near natural as we have been able to devise for rearing insects of this class.

A larger cage for hibernating Calosoma adults has been used in our breeding experiments. It is made of galvanized iron wire, 2 feet in width and with a three eighths inch mesh. A strip was cut and rolled into a cylinder, the diameter of which was 5 inches; the overlapping edges were laced with copper wire and the top and bottom, which were made of wire mosquito netting, were sewed on with wire. The cage was sunk 20 inches in the ground and furnished excellent conditions for hibernating these insects.

It is perfectly true that breeding devices must be used which are especially adapted to the habits and character of the insects to be studied, and it may be desirable to modify these cages in such a way as to suit the special needs of the investigator. For the lines of work which we are attempting, the results secured have been very satisfactory and it is hoped that these devices may be of assistance to others engaged in like work.

\title{
REPORT OF THE COMMITTEE APP.OINTED TO ATTEND THE ANNUAL MEETING OF THE AMERICAN ASSOCIATION OF NURSERYMEN
}

At the last annual meeting of this association, a committee was appointed, consisting of Doctor S. A. Forbes, Prof. T. B. Symons and Mr. A. F. Burgess, to attend the annual meeting of the American Association of Nurserymen at Milwaukee, Wisconsin, June 10, 11, 12, 1908 , for the purpose of conferring with the members of that association relative to matters pertaining to nursery inspection and also in regard to the proposed national inspection and quarantine legislation. Doctor Forbes was unable to be present and the committee was represented by the other members.

At the session held on Wednesday morning, June 10, the following report was submitted by Mr. Orlando Harrison of Berlin, Maryland, 
who was the Nurserymen's representative and joint committee on national inspection and legislation:

\section{Mr. President and Members of the American Association of Nurserymen:}

The subject of a national inspection law is one that should receive the attention of every nurseryman. It has been said that a poor law is better than none, and I think we all agree that it is better to have a law enforcing inspection for the benefit of all the fruit-growers, entomologists and the nurserymen.

The question now is "Do you want two laws?" One operated by the state and the other operated by the government from Washington, like the Pure Food and Seed laws, as they are now enforced.

Who is to be supreme, the state or the government, in enforcing them?

At a recent conference of the governors of the various states at Washington, D. C., it was made clear that the states, so far as their governors were concerned, are scrupulously opposed to relinquishing to the federal government any of the powers reserved to them under the constitution. Practically every governor present went on record in favor of the states exercising their power to the fullest degree, but in doing this, they also made it clear that they, likewise, favored the exercise by the federal government in the fullest sense of all the powers delegated to it by the states through the constitution. The concensus of opinion seems to be that the states must do their work, the nation its work.

\section{When Federal Power Should Prevail}

President Roosevelt has gone on record as recognizing the rights of the states and says in matters that relate only to the people within the state, the state is to be sovereign and it should have the power to act. If the matter is such that the state itself cannot act, then he pleads on behalf of all the states that the national government should act.

\section{Each Must Exercise Its Power}

William Jennings Bryan says he is jealous of any encroachment upon the rights of the state, believing that the states are indestructible as the Union is indissoluble, and it is just as imperative that the general government shall discharge the duties delegated to it as it is that the states should exercise the powers reserved to them. He further says, "Nothing that is necessary is impossible."

\section{State Rights}

Without state rights we would have no government. Eliminate state rights and you have nothing.

\section{Advantage of a National Law}

One thing that could be gained in a national law is to outline a standard law and ask all the states to amend their laws to conform to that as far as practicable. We must remember that the United States government has no power except that given it by the states.

Now it must be taken for granted that the American Nurserymen thought it necessary that something should be done or this committee would not have 
been named. I have diligently tried to work out some plan whereby we could all work under one iaw and all the states share alike.

\section{State Laws Will Remain in Force}

If we have a national law, it is quite evident that the state laws will remain in force, but it is possible that the secretary of agriculture conduct the inspection of nurseries through the present state officials, thus allowing only one inspection of our nurseries, which is desirable; on the other hand, it is not desirable that we have two inspections by separate parties.

\section{A Meeting of the Committee}

I attended the meeting of the American Association of Horticultural Inspectors and Economic Entomologists held in Chicago December 27 and 28, 1907. Before going to the meeting I sent out eighty-eight letters to the largest growers of nursery stock in the association and received sixty replies, the majority of which favored a national law.

You are all familiar with the resolutions passed by the inspectors and entomologists, which have been published by the trade papers.

[See pages 3-4 and 222-23 of the February and June issues of the Journal for copies of these resolutions. ED.]

\section{The Nurseryman's Side}

I said, "The nurserymen are anxious to coöperate with you in combating, controlling and stamping out, if possible, the insect pests and diseases which are liable to be found in the nursery. We realize that it is our duty to our customers and to the man in authority who issues the certificate that they be placed in the proper light with each other and with the grower in issuing the certificate from one state to another. Yet it does seem to us that more stress should be laid by the inspectors upon neglected orchards near a nursery."

\section{Entomologists}

I wish it clearly understood after being with the horticultural inspectors and economic entomologists twice at different meetings, I find they are a class of high grade men and are endeavoring to the best of their ability to bring about uniformity in their inspection work. They have their troubles as well as the nurserymen and are trying to solve the problem now before us.

On my return from Chicago, I found several letters from influential nurserymen denouncing most emphatically that any action should be taken without further consideration and presenting the whole matter before the nurserymen at this meeting. I consulted several leading nurserymen and their advice was that every member of the association should be heard.

On May 12 I sent out four hundred and sixty letters and have received replies from two hundred and twenty-five, of which one hundred and seventy have asked for a national or uniform law; twelve against and five neutral.

of the entomologists or inspectors, thirty-one are favorable and two are opposed.

While many want a uniform law, they want only one law and some do not want a national law. But few who ask for a national law offer any suggestions.

I will give you a few hints from some of the letters received. 


\section{From Nurserymen Who Favor}

"I have for years thought that there ought to be inspectors at every port of entry to the United States. Of course they could not carefully inspect the contents of every case unless there were strong suspicions, but think they could do a great deal to awaken people elsewhere.

"Then I believe there should be other inspectors to inspect the stock at the nurseryman's place before it is distributed all over the country. Just think what a benefit it would have been to the country if there had been such an inspector in California before the scale was carried all over the country."

Another says: "I favor a national uniform inspection law. I think the gains would be impartiality and uniformity of inspection. This, I think, would soon bring about a modification of the practices in different states, rendering it easier and safer to do interstate nursery business."

Another writes: "I favor a national law because this will place all nurserymen upon an equal basis and do away with the endless delays and troubles on account of the various state laws."

\section{Against a National Inspection Law}

Another says: "If national inspection is desired it should include not only nurseries, but orchards, and compel all to keep clear of all kinds of pests."

Another says: "We favor a law that would be equally as stringent upon the fruit grower as well as the nurserymen and all others who own trees of any kind."

Another says: "The writer has recently had a hearing in Washington in regard to a proposed seed law and is none too strong for legislating any industry into federal restrictions or penitentiary penalties and bureaus. The only use for a national law is as a guide for state laws and if it is to be such, the same should be most conservatively and carefully considered. Every person interested commercially should be given an opportunity to be heard.

"The present idea of pernicious activity in federal legislation which will soon put every business man in many unprotected and defenseless industries into the position of working under the possibilities of a prison sentence is not an ideal occupation, in my judgment, for our congressmen."

Another: "We certainly are not in favor of the nurserymen spending any time or money in trying to procure a national uniform inspection law. Congress has no power whatever to change the different state laws and all shipments made would be subject to the different state laws just as soon as they crossed the state line.

"If we could have had a national law passed years ago before all the states had passed their own different laws, we think it would have been a good thing, but so far as we can now see, it would be simply putting one more burden upon the shippers with no corresponding benefits. We would simply have the provision of a national law to comply with in addition to the provision of every state into which we may be shipping.

"We do not know that we have any objection to a national uniform law only as stated above and we should be very much afraid that there would not be an appropriation made so that all nurserymen could have their nurseries inspected.

"We think at the stage to which the matter has now arrived, it would be a 
good deal better to devote our energies to getting the state laws somewhat more uniform than to try to have a national bill passed."

Another says: 'There are some 'IFS' in it.

"If all state laws were abolished or amended to conform to the national law, that would be all right, but they will not amend or abolish because that would be looked on as interference with that time-honored proposition of 'state rights.'

"If we could have a good national law to cover the whole business and all state laws out of the way, it would be a great gain, but as it appears to me, it would make further complications just now to try to have a national bill passed. We might have a national law to cover importations from foreign countries, provided it could be made to harmonize with the present state laws. As the matter stands, I do not feel that there is much to gain in the proposed legislation."

SUMMING UP THE WHOLE MATTER: The last letter puts it in a nutshell and it is now for you to decide-

First: If all state laws were abolished or amended to conform to a national law, that would be all right.

Second: They will not amend or abolish.

Third: What are we to gain by adding another law?

Fourth: Will it help the entomologists and inspectors in doing more efficient work or help the fruit-growers by adding another inspection?

I want to say I have given this some little time and quite a good deal of thought, and, after doing so, I would recommend that a resolution looking forward to making some definite arrangement for inspecting imported stock be adopted. But further than that I have no recommendation to make other than that based on the report.

Orlando Harrison,

Committee on National Inspection Law.

The members of the visiting committee were then called upon for remarks. The purpose of the resolution which had previously been endorsed by the Association of Economic Entomologists and the Association of Horticultural Inspectors was fully explained and national legislation was pointed out as the best method of bringing about uniform regulations and practice in the inspection for stock received from foreign countries or for stock passing into interstate commerce. A motion was made and seconded that the report be accepted and, after a general discussion of the matter in which several nurserymen expressed their opinion that any national legislation was undesirable, it was passed unanimously.

At the afternoon session a resolution was offered by Mr. Kelsey of New York which was unanimously adopted and is as follows:

Resolved, That the vice-president of each state be and hereby is authorized on behalf of this association to use all reasonable endeavor to have any drastic legislation now in force in his state modified to conform to the laws of other states, the practical workings of which have not entailed undue hardship to the nurserymen or fruit-growers in their execution of such laws. 
Resolved, That we heartily express our appreciation of the efforts made by the economic entomologists and horticultural inspectors of the country in their coöperation toward improving the insect pest legislation.

At the morning session, Thursday, the following resolution was presented by Mr. Hale of Tennessee which was designed to carry into effect the report which was adopted on the preceding day :

Resolved, That the American Association of Nurserymen in convention assembled do hereby endorse the passage of a law by Congress providing for the government inspection of all imports as follows:

SECTION 1. That it shall be the duty of the secretary of agriculture and he is hereby authorized and directed to prepare and promulgate rules and regulations governing importations of any trees, plants, shrubs, vines, grafts, cuttings and buds, commonly known as nursery stock, liable to harbor insect pests or plant diseases either by inspection by competent government employes of the United States Department of Agriculture, or by proper certification from officers of the nation or state from which such shipments were made, provided the same are accepted by the secretary of agriculture. When any such aforesaid nursery stock is offered for entry during the dormant season at any port in the United States, it shall be the duty of the secretary of agriculture, with the approval of the secretary of the treasury, to promulgate rules and regulations governing the inspection of said nursery stock at its destination. All nursery stock imported in accordance with the aforesaid regulations shall be free from all further inspection, quarantine or restrictions in interstate commerce; provided, however, that nothing herein contained shall prevent the inspection of such nursery stock by the authorized inspectors of any state or territory or the District of Columbia at the point of destination in accordance with the laws of said state or territory; and that sufficient appropriation be made by congress for this purpose.

Resolved further. That the committee on legislation of this association is hereby instructed to coöperate with the entomologists and inspectors in urging immediate action by congress.

This brought about a general discussion, several members taking the ground that the whole matter had been disposed of by the action taken on the previous day. Mr. Kelsey rose to a point of order and stated that it was his understanding that this was the case. President Hill ruled that the resolution submitted was in order, and, after a brief debate, it was referred to Mr. Pitkin of New York, who is the Legislative Committee of the Nurserymen's Association. No further report on the matter was presented to the meeting by the Legislative Committee at the remaining sessions.

Respectfully submitted, Thomas B. Symons,

A. F. Burgess, Members of Committee. 


\section{$2 \mathrm{BHL}$ Biodiversity Heritage Library}

Symons, Thomas B. and Burgess, A. F. 1908. "Report of the committee appointed to attend the Annual Meeting of the American Association of Nurserymen." Journal of economic entomology 1(4), 269-274. https://doi.org/10.1093/jee/1.4.269.

View This Item Online: https://www.biodiversitylibrary.org/item/37189

DOI: https://doi.org/10.1093/jee/1.4.269

Permalink: https://www.biodiversitylibrary.org/partpdf/325880

\section{Holding Institution}

New York Botanical Garden, LuEsther T. Mertz Library

\section{Sponsored by}

The LuEsther T Mertz Library, the New York Botanical Garden

\section{Copyright \& Reuse}

Copyright Status: NOT_IN_COPYRIGHT

This document was created from content at the Biodiversity Heritage Library, the world's largest open access digital library for biodiversity literature and archives. Visit BHL at https://www.biodiversitylibrary.org. 